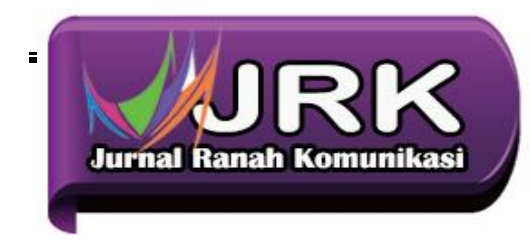

\title{
KOMUNIKASI PENDIDIKAN ANAK DI TENGAH PANDEMI : HOMESCHOOLING SEBAGAI ALTERNATIF PILIHAN ORANG TUA SETELAH SEKOLAH FORMAL
}

\author{
Mira Hasti Hasmira1) \\ 1) Jurusan Sosiologi/ Fakultas Ilmu Sosial, UNP, E-mail: mirahasti@ fis.unp.ac.id
}

\section{ARTICLE INFORMATION}

KEYWORDS:

homeschooling, pandemic, communication

\section{CORRESPONDENCE}

Phone: +6282174412679

E-mail: mirahasti@fis.unp.ac.id

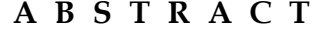

The Covid 19 pandemic has devastated the education system in Indonesia. Children who should enjoy education in formal schools using face-to-face methods, change to distance learning. This raises new problems. To overcome this, it is very necessary to communicate proper education so that children's education can continue as it should. One of the alternative choices for children's education by parents due to the pandemic is homeschooling. homeschooling enthusiasts are soaring amid this pandemic. This paper examines the educational communication that occurred in the implementation of homeschooling in the midst of the Covid 19 pandemic. This paper is in the form of descriptive qualitative data collection methods through participatory observation, interviews and documentation study. The findings in this paper are analyzed using Bruner's learning theory, which focuses on how a person influences others so that the learning process occurs within him. Analysis was also carried out with William Schutz's Fundamental Interpersonal Relationship Orientation (FIRO). This theory emphasizes three kinds of human needs, namely the need for inclusion, the need for control and the need for affection. The result of this research is that educational communication occurs effectively considering that between communicators, namely parents as teachers and children as students and communicants know each other very well, so that parents as teachers can choose and use appropriate teaching methods according to the character of their children. and able to reduce distraction. Teaching materials are also tailored to the needs of children. Besides the national curriculum, parents can also add material that is in accordance with the character of the child.

\section{PENDAHULUAN}

Pada tanggal 24 Maret 2020 Menteri Pendidikan dan Kebudayaan Republik Indonesia mengeluarkan Surat Edaran Nomor 4 Tahun 2020 Tentang Pelaksanaan Kebijakan
Pendidikan Dalam Masa Darurat Penyebaran Covid, dalam Surat Edaran tersebut dijelaskan bahwa proses belajar dilaksanakan di rumah melalui pembelajaran daring/jarak jauh dilaksanakan untuk memberikan pengalaman 
belajar yang bermakna bagi siswa. Belajar di rumah dapat difokuskan pada pendidikan kecakapan hidup antara lain mengenai pandemi Covid-19 (Wahyu Aji Fatma Dewi : 2020).

Meski kebijakan diam di rumah untuk mencegah penyebaran Covid-19 menjadi kesempatan untuk kumpul bersama keluarga, tetapi ada beberapa tantangan yang dihadapi orangtua dalam mendampingi anak. Tantangan itu mulai dari kebosanan yang mungkin dirasakan anak-anak, kemampuan orangtua untuk menggantikan peran guru di sekolah, hingga fasilitas yang dimiliki. "Apakah kita punya kemampuan untuk mengasuh anak kita? Salah satunya adalah kebosanan (anak)," kata Child Protection Specialist UNICEF Indonesia, Astrid Gonzaga Dionisio dalam konferensi pers di BNPB, Kamis (2/4/2020). " Anak kita adalah anak yang dinamik, enerjik, sesuai perkembangannya ingin dekat teman-temannya. Apalagi anak remaja yang lebih nyaman bersama teman sebaya dibandingkan orangtua. (Suryani dalam Tabi'in: 2020).

Masyarakat resah karena pembelajaran daring dinilai sangat memberatkan terutama dari segi ekonomi. Karena kemampuan ekonomi keluarga setiap siswa berbeda-beda. Dalam hal ini banyak orang tua siswa yang keberatan, terutama masyarakat menengah ke bawah, yang masih memiliki kekurangan fasilitas gawai atau gadget. Bahkan sebenarnya hampir tiap kepala keluarga yang terkena dampak ekonomi akibat pandemi Covid-19 ini kesulitan memberikan fasilitas penunjang pembelajaran daring yang memadai bagi anak mereka.

Seperti yang kita ketahui, tidak semua siswa memiliki gadgetnya sendiri, terutama sebagian besar siswa di Sekolah Dasar yang masih harus meminjam gadget orangtua mereka untuk belajar. Namun, orang tua juga memiliki kewajiban untuk bekerja. Waktu mereka bekerja cenderung bertabrakan dengan waktu-waktu anak mereka sekolah. Sehingga tidak sepenuhnya orang tua mampu meluangkan waktunya untuk mengayomi belajar anak dan meminjamkan gadgetnya kepada mereka pada saat pembelajaran berlangsung.

Bagi orangtua siswa yang masih mampu meluangkan waktu nya untuk membantu anak mereka belajar pun masih memiliki kendala. Sudah lumrah kita ketahui bersama bahwa kemampuan penguasaan aplikasi pembelajaran online bagi orang tua siswa pun berbeda-beda. Orang tua siswa terkadang cenderung "baru" dan belum paham dalam menggunakan segala hal berbau IT, begitupun jika dihadapkan dengan penggunaan aplikasi pembelajaran online yang dinilai menyulitkan untuk digunakan.

Tidak hanya itu, bahkan beban kuota juga menjadi tanggungan yang besar. Apalagi dalam keadaan krisis ekonomi sejak pandemi Covid19 melanda, mengingat sebagian besar bahan ajar yang diberikan kepada siswa cenderung lebih banyak menggunakan kuota berlebih karena beberapa bahan ajar harus diakses melalui video online ataupun youtube.

Di Indonesia sendiri didapati beberapa kasus kriminal pencurian yang dilakukan oleh oknum siswa atau orangtua siswa dengan motif lantaran ketidakmampuan keluarga dalam membeli kuota atau gadget untuk menunjang kegiatan pembelajaran daring. Suatu hal yang ironis. Disaat pendidikan bertujuan untuk mendidik dan membangun nilai-nilai karakter justru dengan keadaan terdesak untuk memenuhi fasilitas pembelajaran daring, nilai-nilai karakter malah kian mengalami kemerosotan. (netkepri.com : 2020)

Tidak sedikit juga status para orang tua yang bermunculan di media sosial terkait komplain dengan sistem pembelajaran yang berlaku pada masa pandemi Covid 19. Istilah "daring v.s darting" (pembelajaran daring versus darah tinggi) kemudian menjadi viral akibat kebingungan orang tua mengajar anak di rumah.

Survei Komisi Perlindungan Anak Indonesia (KPAI) menemukan sebanyak 79,9 persen siswa mengaku proses belajar dari rumah tak berlangsung interaktif. Mayoritas responden 
dari total 1.700 anak ini disebut tak berinteraksi sama sekali dengan guru kecuali saat memberikan dan mengumpulkan tugas. Survei dilakukan kepada siswa SMA hingga TK di 20 provinsi dan 54 kabupaten/kota. Tim peneliti menggunakan teknik multistage random sampling yang dilakukan dalam kurun waktu 13 April hingga 20 April 2020. (cnnindonesia.com)

Pembelajaran online yang berlangsung mulai dari tingkat dasar hingga perguruan tinggi, ditemukan sangat terkendala pada siswa sekolah dasar. Anak-anak sangat tergantung pada orang tua dalam penggunaan internet dan fasilitas seperti andorid yang rata-rata hanya dimiliki oleh orang tua. Berikut adalah data penggunaan internet pada siswa usia 5-24 tahun

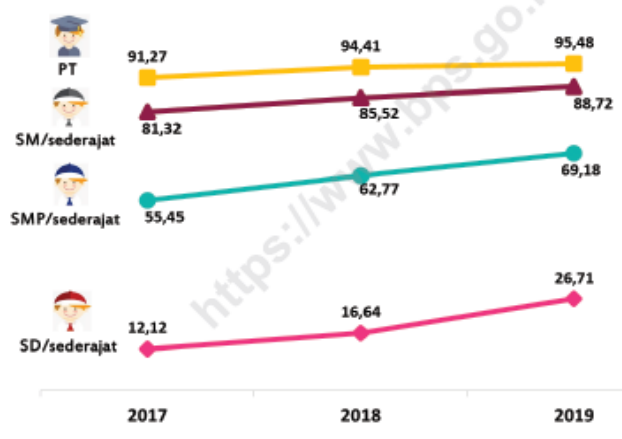

Sumber : bps.go.id

Gambar 1. Perkembangan Persentase Siswa Usia 5-4 Tahun yang Menggunakan Internet Menurut Jenjang Pendidikan,

2017-2019

Akibat permasalahan diatas maka memunculkan homeschooling (sekolah rumah) sebagai alternatif pilihan bagi orang tua dalam melanjutkan pendidikan anak-anaknya terutama pada usia sekolah dasar. homeschooling (sekolah rumah) sebenarnya sudah lama dikenal masyarakat, namun kembali menjadi topik pembicaraan sejak pandemi Covid 19 ini.
Pendidikan alternatif dapat berfungsi sebagai substitute, suplemen dan komplemen terhadap pendidikan sekolah. Sebagai substitute, artinya dapat menggantikan pendidikan jalur sekolah yang karena beberapa hal masyarakat tidak dapat mengikuti pendidikan dijalur persekolahan (formal), sebagaimana sudah terlaksana selama ini adalah Kejar Paket A, B, dan C. Sebagai suplemen, diartikan bahwa pendidikan alternatif dilaksanakan untuk menambah pengetahuan, keterampilan yang kurang didapatkan dari pendidikan sekolah, seperti les privat, dan training. Sedangkan sebagai komplemen berarti bahwa pendidikan alternatif dilaksanakan untuk melengkapi pengetahuan dan keterampilan yang kurang atau tidak dapat diperoleh di dalam pendidikan sekolah, sebagaimana terjadi melalui kursus, try out, dan pelatihan. (Purnamasari : 2017)

Dalam dunia pendidikan terdapat 3 jalur pendidikan yaitu formal, informal, dan non formal. homeschooling termasuk dalam pendidikan informal. Metode pendidikan homeschooling merupakan metode pendidikan berbasis keluarga, dimana model pembelajarannya dilakukan di rumah dengan orang tua atau dengan guru privat. Artikel ini lebih lanjut akan mendeskripsikan bagaimana komunikasi yang terjadi dalam pelaksanaan homeschooling (sekolah rumah).

Penelitian-penelitian mengenai sekolah rumah sudah banyak dilakukan. homeschooling Dalam Masyarakat:

Studi Etnografi Pendidikan yang dilakukan Iin Purnamasari, Suyata, Siti Irene Astuti Dwiningrum. Penelitian menemukan lima hal pokok yaitu; (a) pilihan terhadap homeschooling sebagai pendidikan alternatif dengan model praktik tunggal, majemuk dan komunitas memiliki alasan, motivasi, metode dan pendekatan serta pengembangan minat bakat anak serta upaya membangun masa depan anak. (b) peran keluarga pada homeschooling tunggal 
dominan, majemuk diberdayakan, dan komunitas sebagai pendekatan, dimana masingmasing terpengaruh oleh penanaman nilainilai dalam budaya keluarga. (c) formula model pendidikan homeschooling berbasis kultur yang meliputi penguatan keyakinan, toleransi, mandiri, kejujuran, tanggung jawab, percaya diri, disiplin, kompetitif, solidaritas, sosialisasi lintas usia, dan berpikir kritis, sesuai dengan kebutuhan pendidikan anak. (d) nilai-nilai positif homeschooling antara lain: (a) anak terbentuk sebagai pembelajar mandiri dan terbiasa berpikir mendalam (critical thinking). (b) peran orangtua/keluarga sebagai pengelola pendidikan dan proses belajar. (c) pola pembelajaran customized, (d) penanaman nilai sosial budaya terbangun dari interaksi antara anak dengan orangtua/keluarga, para homeschooler dalam komunitas belajar. (e) terdapat tantangan, harapan dan kemungkinan pengembangan pendidikan homeschooling dalam masyarakat. (Purnamasari : 2017)

Pendidikan Dan Pembelajaran Di Sekolah Rumah (Home Schooling) Suatu Tinjauan Teoritis dan Praktis yang dilakukan oleh Ali Muhtadi. Penelitian ini mengungkap bahwa keberadaan model pendidikan home schooling harus disikapi sebagai sebuah bentuk alternatif model pendidikan dan bangkitnya kesadaran para orang tua akan tanggung jawabnya terhadap pendidikan anak-anak mereka. (Muhtadi : 2011)

Gangguan Proses Komunikasi Dalam Home Schooling Antara Ayah Dan Anak Fenny Anggraini. Penelitian mengungkap terdapat beberapa gangguan komunikasi pendidikan yang terdiri dari gangguan fisik, gangguan fisiologis, gangguan psikologis dan gangguan semantik. (Anggaini : 2018)

Kelas Komunitas Menunjang Terciptanya Karakter Komunikatif Peserta Didik homeschooling Palembang
Yang dilakukan oleh Rosda Fajri Kafarisa \& Muhammad Kristiawan. Hasil penelitian menunjukkan adanya kelas komunitas yang diadakan setiap seminggu sekali dilakukan Siswa homeschooling Primagama bisa bekerja sama dan bergaul tanpa memperdulikan usia dan pendidikan, serta dapat bersosialisasi dengan lingkungan sekitarnya. (Kafarisa : 2018)

Interaksi Sosial Pada Anak Yang Mengikuti Metode Pendidikan homeschooling yang dilakukan oleh Mufi Wijayanti dan Nanik Prihartanti. Hasil dari penelitian ini adalah anak yang mengikuti homeschooling terjadi interaki sosial yang bagus dengan orang tua dan keluarga, karena orang tua dan keluarga memiliki peran yang sangat penting dalam mensukseskan pendidikan anak sehingga orang tua atau keluarga bertanggung jawab penuh, namun ketika betemu dengan masyarakat luas kurang mampu bersosialisasi dengan cakap. Hal tesebut terjadi karena anak yang mengikuti metode pendidikan homeschooling menuangkan semua waktunya berada di homeschooling dan kegiatan kesibukan masing-masing sehingga interaksi dengan masyarakat di lingkungan sekitar rumah sangat minim dan jarang terjadi. Dalam pemilihan kegiatan atau kesibukan homeschooler lebih mengedepankan bakat dan potensi yang dimiliki, disamping itu juga untuk menumbuhkan rasa percaya diri sehingga diperbanyak kegiatan yang menunjang hal tersebut. (Wijayanti : 2015)

Skema Komunikasi Keluarga homeschooling (Studi Kasus mengenai Orientasi Komunikasi dan Konformitas dalam Keluarga homeschooling di Komunitas homeschooling Klub OASE) Kesimpulannya, keluarga homeschooling berkomunikasi secara aktif dan terbuka melaksanakan pendidikan. Orang tua dan anak dapat berbagi cerita, berdiskusi, dan menyelesaikan masalah pendidikan bersama. Dalam penyesuaian nilai-nilai penting ditemukan tingkat kesesuaian yang berbeda 
karena konteks pendidikan. Orang tua homeschooling dukung anak-anak untuk bertindak dan berkembang secara mandiri. Sedangkan dalam pengambilan keputusan dan komitmen, orang tua dapat dengan tegas mengambil keputusan untuk pendidikan keluarga. Ditemukan juga bahwa mentor homeschool memiliki kontribusi dalam keluarga komunikasi. Mentor berperan sebagai mediator bagi orang tua dan anak dalam pembelajaran proses. Berdasarkan temuan ini, keluarga homeschool di Klub Oase termasuk dalam kategori tipe keluarga pluralistik dan konsensual. (Anindita : 2019)

Dari beberapa penelitian yang ada, belum ada yang menjelaskan tentang bagaimana komunikasi yang berlansung dalam proses pendidikan anak dengan metode sekolah rumah (homeschooling). Oleh karena itu, berikut akan dijelaskan bagaimana komunikasi yang berlangsung dalam proses pendidikan anak dengan metode sekolah rumah (homeschooling)

\section{METODOLOGI PENELITIAN}

Penelitian ini menggunakan pendekatan kualitatif deskripstif dengan tipe studi kasus. Dengan studi kasus, diharapkann dapat mendeskripsikan secara lebih gamblang tentang komunikasi pendidikan yang terjadi pada pembelajaran homeschooling. Informan pada penelitian ini diambil dengan teknik puposive sampling, yaitu keluarga pelaku homeschooling. Keluarga yang memilih homeschooling karena pandemi Covid 19 sebanyak 3 keluarga dan keluarga yang sudah memilih jalur homeschooling jauh sebelum pandemi datang sebanyak 5 keluarga. Total jumlah keluarga yang menjadi informan penelitian adalah 8 keluarga, yang teresebar di Jakarta, Bandung dan Padang. Jenis homeschooling yang menjadi fokus penelitian adalah homeschooling tunggal. Metode pengumpulan data yang dilakukan adalah melalui angket google form, wawancara dan observasi. Sedangkan analisis dilakukan dengan teknik analisis Miles dan Huberman.

\section{HASIL DAN PEMBAHASAN}

Seperti diuraikan sebelumnya, komunikasi pendidikan secara sederhana adalah komunikasi yang terjadi dalam suasana belajar. Untuk lebih memudahkan menggambatkan bagaimana komunikasi yang berlangsung, penulis menjelaskan melalui komponen-komponen dalam komunikasi.

Harold Lasswell mencoba untuk mendefinisikan komunikasi dengan mengeluarkan sebuah paradigma yang sangat terkenal. Paradigma tersebut merupakan sebuah cara yang digunakan untuk memahami komunikasi dengan menjawab pertanyaan Who Says What In Which Channel To Whom With What Effect?. Dari paradigma tersebut, dapat kita lihat bahwa komunikasi terdiri dari berbagai unsur, yaitu sumber, pesan, media, penerima pesan, dan efek. Berikut akan dijelaskan seperti apa komunikasi yang berlangsung dilihat dari komponen-komponen komunikasi yang ada, sebagai berikut : 


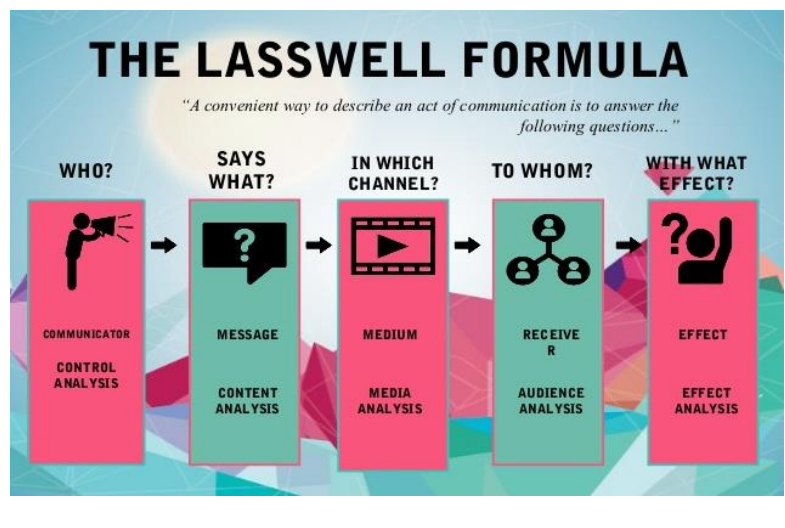

Sumber : dictio.id

Gambar 2. Model Komunikasi Lasswell

\section{Komunikator}

Dalam proses komunikasi, yang menjadi sumber komunikasi adalah sender atau pengirim pesan. Komunikator adalah seseorang yang mengirimkan pesan. Terdapat beberapa faktor dalam diri komunikator yang menentukan efektivitas komunikasi yaitu sikap komunikator dan pemilihan berbagai simbol yang penuh makna. Yang dimaksud dengan sikap komunikator adalah bahwa komunikator harus memiliki sikap yang positif. Sementara itu, yang dimaksud dengan pemilihan berbagai simbol yang penuh makna yang dilakukan oleh komunikator adalah bahwa pemilihan simbolsimbol yang tepat bergantung pada siapa yang menjadi khalayak sasaran dan bagaimana situasi lingkungan komunikasi. Dengan demikian, untuk menjadi komunikator yang baik, terdapat beberapa hal yang harus kita pertimbangkan, diantaranya adalah harus mengenali siapa yang menjadi komunikate/penerima pesan/khalayak sasaran.

Pada komunikasi pendidikan pembelajaran sekolah rumah, yang bertindak sebagai komunikator adalah orang tua dan anggota keluarga lainnya. Pada penelitian yang dilakukan, komunikator ini dinominasi oleh ibu. Ketika akan belajar, orang tua sangat memperhatikan kondisi mood atau kesiapan anak, jika anak terlihat kurang siap maka orang tua akan mengkondisikan anak agar kembali tertarik untuk belajar. Disini terlihat bahwa orang tua (ibu) sangat mendominasi dalam pemilihan simbol dan situasi lingkungan saat komunikasi berlangsung. Saling mengenal yang baik antara orang tua (ibu) dan anak danam proses pembelajaran ini sangat mempengaruhi berhasilnya proses belajar dalam homeschooling.

\section{Pesan}

Yang dimaksud dengan pesan adalah informasi yang akan kita kirimkan kepada komunikate/penerima pesan/khalayak sasaran. Pesan yang kita kirimkan dapat berupa pesanpesan verbal maupun pesan nonverbal. Agar pesan menjadi efektif, maka komunikator harus memahami sifat dan profil komunikate/penerima pesan/khalayak sasaran, kebutuhan khalayak sasaran, serta harapan dan kemungkinan respon yang diberikan oleh komunikate/penerima pesan/khalayak sasaran terhadap pesan yang dikirimkan. Hal ini sangat penting baik dalam komunikasi tatap muka maupun komunikasi bermedia. Tanpa adanya pesan, maka kita tidak memiliki alasan untuk melakukan komunikasi. Jika kita tidak dapat mengemas informasi dengan baik, maka kita belum siap untuk memulai proses komunikasi

Demikianpun dalam komunikasi yang berlangsung dalam homeschooling. Dalam mempersiapkan materi ajarnya kepada sang anak 
ditemukan bahwa para $62,5 \%$ orang tua homeschooler memilih untuk belajar mandiri. Sisanya mengikuti pelatihan-pelatihan homeschooling, mengamati minat dan bakat anak untuk menyalurkan ke jalur yang semestinya. Kelebihan yang dimiliki pembelajaran homeschooling adalah, orang tua dapat memilih apa yang diajarkan sesuai dengan apa yang dibutuhkan anak, artinya orang tua bisa membuat sendiri kurikulum yang sesuai bukan anak yang menyesuaikan dirinya dengan kurikulum yang ada. Hal ini dilakukan agar pesan-pesan yang ingin disampaikan melalui proses belajar dapat disampaikan dengan baik.

Salah seorang anak homeschooling yang ditemui, sangat antusias menjelaskan kelas animasi yang dia ikuti. Selama mengikuti sekolah formal, si anak sering ditegur guru akibat terlalu sering menggambar.setelah ibu menanyakan apa kemauan anaknya, si anak mengatakan ingin menjadi seorang animator. Setelah memilih pindah ke jalur homeshooling dan meninggalkan sekolah formal, si anak difasilitasi untuk mengikuti kelas animasi secara online oleh orang tuanya. Anak dapat lebih menyalurkan minat dan bakatnya secara lebih total. Dalam jangka waktu lebih kurang 2 bulan, si anak sudah mampu berkarya dan sudah mengunggah komiknya di webtoon, sebuah aplikasi asal Korea Selatan yang menyajikan komik secara online. Untuk anak dengan usia 10 tahun, informan ini sangat mengagumkan. Disamping itu, anak ini juga sudah mempunyai channel youtube dengan konten-konten seputar karyanya dan tutorial membuat animasi.
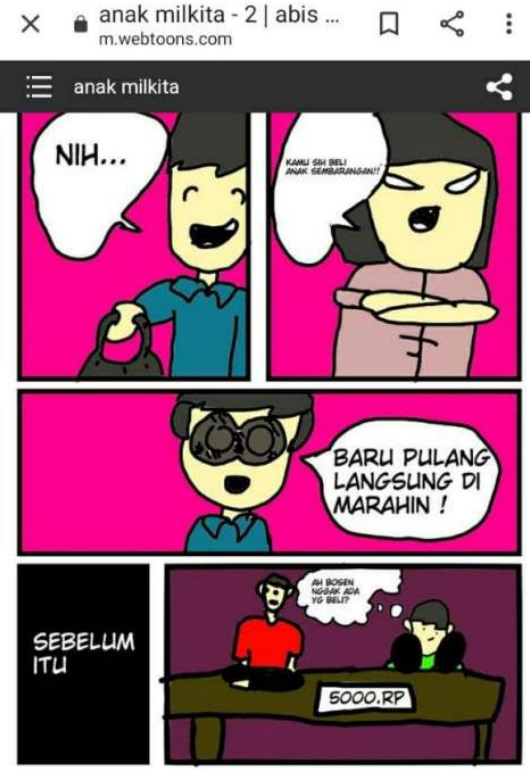

Penulis Akio Budiman penculikan anak

Sumber : webtoon

Gambar 3. Salah Satu Karya Anak homeschooling

\section{Media}

Media atau saluran komunikasi adalah media atau berbagai media yang kita gunakan untuk mengirimkan pesan. Jenis pesan yang kita miliki dapat membantu kita untuk menentukan media atau saluran komunikasi yang akan kita gunakan. Yang termasuk ke dalam media atau saluran komunikasi adalah kata-kata yang diucapkan, kata-kata yang tercetak, media elektronik, atau petunjuk nonverbal. Dalam komunikasi modern, yang dimaksud media atau saluran komunikasi sebagian besar merujuk pada media komunikasi massa seperti radio, televisi, dan lain-lain serta internet sebagai media komunikasi. Pemilihan media atau saluran komunikasi yang tepat dapat menentukan sukses tidaknya komunikasi yang kita lakukan

Dalam homeschooling, media pembelajaran yang digunakan para homeschooler disamping kata-kata, juga memanfaatkan media belajar lainnya. Ditemukan sebanyak 50\% informan penelitian menjawab menggunakan atau 
memanfaatkan media yang ada di rumah atau sekitar rumah. Sisanya mengatakan membeli media belajar dan menggunakan internet. Seperti gambar di bawah ini, salah seorang anak homeschooling sedang belajar IPA tentang Organ Gerak. Orang tua membawa anak belajar di alam terbuka.
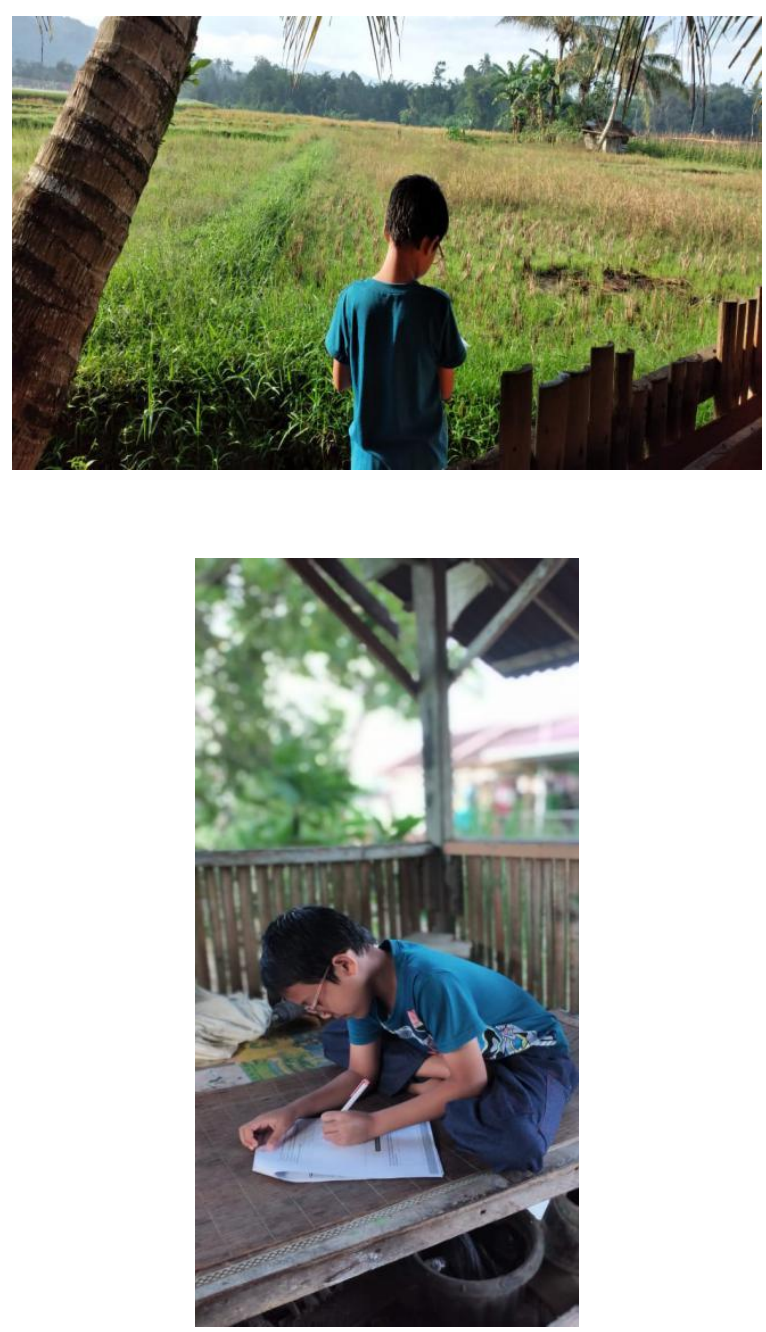

Sumber : Dokumentasi Peneliti

Gambar 4. Anak homeschooling Sedang Belajar di Alam Terbuka

\section{Komunikan}

Komunikasi tidak akan terjadi tanpa kehadiran komunikate/penerima pesan. Ketika komunikate/penerima pesan menerima sebuah pesan, maka ia akan menafsirkan pesan, dan memberikan makna terhadap pesan yang diterima. Komunikasi dapat dikatakan berhasil manakala komunikate/penerima pesan/ menerima pesan sesuai dengan apa yang diinginkan oleh komunikator

Komunikaan dalam hal ini adalah anak (usia sekolah dasar). Kelebihan pelaksanaan sekolah rumah bagi anak adalah, karena antara anak dan orang tua sudah sangat saling mengenal, sehingga gangguan-gangguan dalam komunikasi dapat dihindari, terutama gangguan psikologis. Akhirnya, komunikan dapat lebih cepat menangkap makna pesan yang disampaikan oleh komunikan. Hal ini akan sangat berbeda jika anak berada di sekolah formal dengan guru yang banyak dan bergantian masuk ke dalam kelas. Anak akan butuh waktu lama untuk bisa menyesuaikan diri dan untuk mau bertanya berkaitan dengan materi pembelajaran.

\section{Umpan Balik (Feedback)}

Apapun media atau saluran komunikasi yang digunakan untuk mengirimkan pesan, kita dapat menggunakan umpan balik untuk membantu kita menentukan sukses tidaknya komunikasi yang kita lakukan. Jika kita berada dalam komunikasi tatap muka dengan komunikate/penerima pesan, maka kita dapat membaca bahasa tubuh dan memberikan pertanyaan untuk memastikan pemahaman. Jika kita berkomunikasi secara tertulis maka kita dapat mengetahui sukses tidaknya komunikasi melalui respon atau tanggapan yang kita peroleh dari komunikate/penerima pesan. Dalam beberapa kasus, umpan balik memiliki peran yang tak ternilai dalam membantu kita sebagai komunikator untuk memperbaiki keterampilan komunikasi. Kita dapat belajar apa yang berjalan dengan baik dan apa yang tidak sehingga kita dapat berlaku secara efisien ketika kita melakukan komunikasi di lain waktu. 
Dalam homeschooling yang diteliti, Sebanyak $62,5 \%$ informan menjawab bahwa anak senang dan menikmati belajar di rumah, namun 25\% mengaku kadangkala anak ingin kembali ke sekolah karena rindu dengan teman-temannya, sedangkan sisanya senang belajar dimana saja sesuai dengan minat anak. Anak-anak yang pernag mengecap pendidikan formal dan kemudian pindah ke homeschooling, 57,1\% mengatakan berkembang lebih baik dibandingkan ketika masih berada di sekolah formal. 28,6\% anak memiliki kesempatan yang lebih banyak mempelajari bidang yang disukainya dan $14,3 \%$ anak menjadi lebih mandiri. Jika dilihat dari aspek akademiknya, ada homeschooler yang sudah memasuki jenjang perkuliahan dengan emndapatkan jurusan yang sangat diminati dan perguruan tinggi negeri ternama di Pulau Jawa

Jika dianalisis dengan teori pembelajaran bruner, teori telajar yang diambil dari paradigma psikologi humanistik menekankan pada bagaimana individu dipengaruhi dan dibimbing pribadi yang mereka hubungkan kepada pengalaman-pengalaman mereka sendiri atau dengan kata lain pandangan ini berusaha untuk memahami prilaku seseorang dari sudut perilaku ( behaver). Bukan dari pengamat (observer). dalam pembelajaran homeschooling, hubungan saling mengenal yang ada pada orang tua dan anak sangat mempengaruhi proses belajar yang terjasi. Sehingga, orang tua dapat leluasa membimbing anak menjadi pribadi yang mereka harapkan. Akhirnya, materi akademik dan terutama pembangunan karakter yang diinginkan oleh orang tua dapat tercapai dengan baik.

Disamping itu, temuan juga dianalisis dengan Fundamental Interpersonal Relationship Orientation (FIRO) dari William Schutz. Teori ini menakankan pada tiga macam kebutuhan manusia, yaitu kebutuhan inklusi, kebutuhan untuk memegang kontrol dan kebutuhan afeksi. Pola hubungan antar pribadi (interpersonal) dapat dijelaskan dalam tiga kebutuhan interpersonal, yaitu Inklusi adalah kebutuhan akan keikutsertaan (togetherness), kebutuhan untuk bergabung dengan orang lain. Kebutuhan tersebut nampak melalui perilaku untuk menarik orang lain dan interest pada orang lain. Orang yang kuat akan kebutuhan inklusi ini akan nampak melalui keinginan untuk dikenal, terkemuka, dsb.

Kebutuhan akan kontrol bervariasi dari kebutuhan untuk mendominasi orang lain sampai kebutuhan untuk dikontrol. Pada satu pihak orang ingin mengontrol orang lain secara mutlak (komplit), sedangkan di pihak lain keinginan untuk dikontrol oleh orang lain secara mutlak. Kebutuhan afeksi adalah erat hubungannya dengan personal dan emotional feeling antara dua individu, dan dalam keadaan ekstrem menjelma dalam cinta dan benci. Orang dengan kebutuhan afeksi yang tinggi akan bersahabat (friendly), pada umumnya akan menciptakan hubungan emosional dengan orang lain. Pada pihak yang lain orang dengan kebutuhan afeksi yang rendah akan menolak hubungan interpersonal yang lekat.

Pada homeschooling juga ditemui saling terpenuhinya 3 kebutuhan yang dipaparkan oleh Schutz ini. homeschooling berawal dari kesepakatan (togetherness) antara anak dan orang tua sebagai sebuah alternatif pendidikan. Dari pengamatan yang dilakukan, terlihat anak dan orang tua sangat bahagia menjalankan pendidikan yang mereka pilih, bahkan, salah satu informan (ibu) mengatakan bahwa sejak anaknya tidak berada di sekolah formal, anaknya menjadi lebih ceria, tidak tertekan dengan bully temanteman di sekolah sehingga berat badannya menjadi lebih proporsional. Kebutuhan kontrol orang tua juga sangat terlihat dlam pembentukan karakter anak, sehingga anak bisa dibentuk dari usia dini menjadi anak-anak yang memiliki karakter baik serta mental yang kuat. Sedangkan 
kebutuhan untuk dikenal (inklusi) terlihat dari para orang tua yang memfasilitasi anak ke bidang yang mereka inginkan.

\section{KESIMPULAN}

Tidak semua anak cocok menjalankan pendidikannya melalui jalur homeschooling (sekolah rumah). bagi anak dan orang tua yang menemukan bahwa homeschooling adalah pilihan yang tepat, maka pembelajaran baik secara akademik maupun pendidikan karakter anak dapat berlangsung dengan baik dengan mencapai target yang diinginkan. Hal ini tentu saja sangat dipengaruhi oleh komunikasi yang berlangsung dalam proses pembelajaran.

\section{DAFTAR PUSTAKA}

Anggraini, F. (2018). Gangguan Proses Komunikasi Dalam Home Schooling Antara Ayah Dan Anak. Jurnal e-Komunikasi, 6(1).

Anindita, m. Skema Komunikasi Keluarga homeschooling.

Asah Pena (2020). Materi Bimtek K13 untuk Sekolah Rumah, 18-19 September 2020

Cangara, H. (2007). Pengantar Ilmu Komunikasi Edisi Revisi. Jakarta: PT Raja Grafindo Persada.

Dewi, W. A. F. (2020). Dampak Covid-19 terhadap implementasi pembelajaran daring di Sekolah Dasar. Edukatif: Jurnal Ilmu Pendidikan, 2(1), 55-61.

https://netkepri.com : Polemik Pembelajaran Daring, Alternatif Atau Masalah Baru $(08 / 08 / 2020)$

https://www.cnnindonesia.com :Menimbang homeschooling, Alternatif Pembelajaran saat Pandemi (29/05/2020)

Faturrohman, Muhammad (2017). Belajar dan Pembelajaran Modern Konsep Dasar, Inovasi dan Teori Pembelajaran.Yogyakarta : Garudhawaca
Kafarisa, R. F., \& Kristiawan, M. (2018). Kelas Komunitas Menunjang Terciptanya Karakter Komunikatif Peserta Didik homeschooling Palembang. JMKSP (Jurnal Manajemen, Kepemimpinan, dan Supervisi Pendidikan), 3(1).

Moh Gufron, Komunikasi Pendidikan Yogyakarta : Kalimedia, 2016

Muhtadi, A. (2011). Pendidikan Dan Pembelajaran Di Sekolah Rumah (Home Schooling): Suatu tinjauan teoritis dan praktis. Majalah Ilmiah Pembelajaran.

O"Connel, Timothy.S and Cuthbertson, Brent (2009). Creating Conscious Groups Through AN Experiental Approach. United States : Human Kinetics.

Purnamasari, I., Suyata, S., \& Dwiningrum, S. I. A. (2017). homeschooling dalam masyarakat: Studi etnografi pendidikan. Jurnal Pembangunan Pendidikan: Fondasi dan Aplikasi, 5(1), 1431.

Safitri, Panduan homeschooling Terelngkap, Kudus : Yayasan Bintang Mulia

Tabi'in, A. (2020). Problematika Stay at Home pada Anak Usia Dini di Tengah Pandemi Covid 19. Jurnal Golden Age, 4(1).

Wijayanti, M. (2015). Interaksi Sosial Pada Anak Yang Mengikuti Metode Pendidikan homeschooling (Doctoral dissertation, Universitas Muhammadiyah Surakarta). 